\title{
Was it Really Present? Feminism in Journalism Coverage of Egyptian Parliamentary Election Campaign
}

\author{
Dr. Mohamed Ahmed Fadl Elhadidi \\ Department of Mass Communication, Faculty of arts, Damietta University, Egypt \\ Email: Mohamed_elhadidi@yahoo.com/Mohamedtaema11@hotmail.com
}

\section{Doi:10.5901/mjss.2014.v5n15p597}

\begin{abstract}
The content analysis of Egyptian journalism coverage of 2010 parliamentary election campaign concluded that the coverage was biased in favor of male candidates who received more attention on male issues than female candidates, whereas female candidates received more attention on female issues than male candidates. Also male and female candidates received different coverage concerning their personal traits, frames and background, but both candidate electability and the slant of coverage were equitable to men and women candidates. Furthermore there were some differences in how male and female journalists covered men and women candidates.
\end{abstract}

Keywords: women candidate; journalism; election campaign; political communication; framing;

\section{Introduction}

In 2007 the election law in Egypt was modified through a constitutional amendment of article 62 mattering the allocation of 64 seats for women in Egyptian parliament known as quota. The aim was to increase seats for women to support their participation in the parliamentary work through competition among themselves, in addition to the possibility to increase the number of 64 seats when competing against male candidates in the parliamentary election.

This new situation, which led to the mandatory representation of women in the parliament, gave a priority to parliamentary work for women to be of concern to all segments of society including media coverage of the event.

In this respect the study looks at how Egyptian journalism portrayed the female candidates in parliamentary elections campaign compared to male candidates. Using previous literature that explored media's portrayal of female candidates in comparison to male candidates, this study relies on a content analysis of articles from major Egyptian newspapers and a news website, extends more understanding about how journalism treated female and male candidates of 2010 parliamentary election campaign in Egypt equitably in terms of the quantity and the quality of coverage.

\section{Literature Review}

Much research has tested media coverage of female candidates running for election by focusing on the measurement of the following areas:

\subsection{The volume of coverage}

Some of previous studies (e.g., Kahn 1994; Kahn \& Goldenberg 1991) have found that female candidates receive less coverage than do their male counterparts. Kahn work led to more research to shed light on the biases of press coverage of both male and female candidates. Some of recent studies (Aday and Devitt 2001; Heldman et al. 2005; Piper-Aiken 1999) confirmed Kahn's findings, whereas others (e.g., Atkeson \& Krebs 2008; Devitt 2002; Smith 1997) revealed no bias in the volume of coverage of male and female U.S Senate and gubernatorial candidates, except in open races. Smith (1997) found men received more coverage, whereas others (e.g., Bystrom et al. 2001) suggested greater coverage of women, specifically that being a woman significantly increases the media attention House members receive (Gershon 2008). 


\subsection{Candidates' issues}

In 1999, Devitt's analysis of the coverage received by male and female candidates for governor indicated that men were more likely to receive coverage on an issue stand or record on political issues than women counterparts. Also Kahn (1993) illuminated that while women candidates really emphasized social issues and men emphasized foreign policy, economics and agriculture, most issue coverage given by the press to any candidate was about these stereotypically "masculine" issues, and when "female" issues were covered by the press, they were indeed covered more extensively when the candidate was a woman. Also others (Bystrom et al. 2001; Smith 1997) concluded that although men's and women's issue coverage was similar on crime and government finances, male candidate coverage consistently emphasized economic concerns. On the contrary, a recent study (Atkeson and Krebs 2008) illuminated that in press coverage of the USA mayoral elections, female candidates did not receive more attention on "female" issues nor did they receive less on "male" issues.

\subsection{Candidates' traits}

In 1994, Kahn's study of female U.S. Senate and gubernatorial candidates indicated that women candidates were advantaged through focusing on feminine traits such as warmth and honesty. However, reporters discussed male personality traits (e.g., toughness, leadership skills, and intelligence) slightly more than female traits (e.g., honesty, and compassion). Also senate races studies found that reporters portrayed men as strong and women as approachable and sensitive (quoted in Devitt 2002: 448). More recent studies, while approaching a content analysis of press coverage of the 2008 presidential nomination campaign, illuminated that mentions of negative traits were significantly elevated for Hilary Clinton versus her Democratic competitors and they tended to emphasize personality faults associated with Clinton (e.g., dishonesty and divisiveness), whereas Barak Obama's coverage tended to emphasize his inexperience (Peake \& Miller 2008), and Hillary Clinton's competence could not overcome a considerable amount of personal and political baggage (Carlin and Kelly 2009: 339). The same manner was in presidential race in Chile press that portrayed female candidate in the traditional female stereotype of care and compassion, while the male candidates were framed in stereotypical masculine manners, described as competent and good leaders (Valenzuela and Correa 2009).

\subsection{The slant of coverage}

Media coverage was negative in some cases (Bystrom 2006a; Carlin and Winfrey 2009; Kahn 1996), but others found viability was mostly equitable (Bystrom et al. 2001; Jalazai 2006; Smith 1997), and Bystrom et al. (2004) suggests that this problem has lessened over time. In Canada, women candidates are described in more negative and aggressive terms than their male counterparts (e.g., Gidengil and Everitt 1999, 2003), but in Chile Dussaillant (2005) found that neutrality was the frame most frequently used by the Chilean press to describe the candidates of the 1999 election (quoted in Valenzuela and Correa 2009: 218). As for candidate electability, male candidates in the local races received coverage as eventual winner more than female candidates in the intergender race (Atkeson and Krebs 2008). In stark contrast other studies (e.g., Valenzuela and Correa 2009) indicated that the female presidential candidate was always described as the likely winner, whereas most coverage of the two male candidates in the campaign depicted them as competitive candidates, but not as likely winners (pp.212-213).

\subsection{Framing female candidate}

Research specifically on the coverage of female and male candidates, while yielding a variety of results, has also demonstrated how the analysis of frames maybe useful in detecting patterns in news coverage (Devitt 2002: 447). Studies of press coverage of gender stereotypes (Aday \& Devitt 2001; Banwart et al 2003; Bystrom 2006a; Devitt 2002; Heldman et al 2005; Kahn 1994; Kahn \& Goldenberg 1991) found female candidates often receive less issue coverage than males, and personal topics such as appearance, clothes, size, age, personality, emotional state, children and marital status were more likely to be about female than male candidates as well as defining female candidates in terms of these roles rather than as a political candidate. These findings on personal coverage at the legislative, state executive and presidential level came in contrast to research of Atkeson and Krebs (2008) on mayoral elections who revealed that in these local races the candidates' proximity to the local media, their personal knowledge and families may lead to less bias on this dimension. 


\section{Hypotheses}

$\mathrm{H} 1$ : There are statistically significant differences in the quantity of Egyptian journalism coverage according to the gender of the candidate.

$\mathrm{H} 2$ : There are statistically significant differences in issues covered in Egyptian journalism according to the gender of the candidate.

H3: There are statistically significant differences in personal traits covered in Egyptian journalism according to the gender of the candidate.

H4: There are statistically significant differences in frames and background covered in Egyptian journalism according to the gender of the candidate.

H5: There are statistically significant differences in candidate slant and electability covered in Egyptian journalism according to the gender of the candidate.

H6: There are statistically significant differences in volume of Egyptian journalism coverage of female and male candidate according to the gender of the editor.

$\mathrm{H} 7$ : There are statistically significant differences in candidate electability and slant covered in Egyptian journalism according to the gender of the editor.

H8: There are statistically significant differences in candidate frames and background covered in Egyptian journalism according to the gender of the editor.

\section{Research Design and Methodology}

To test the study hypotheses, content analysis of three major daily newspapers and an online news website in Egypt was conducted during the campaign. The newspapers sample was adopted according to Al-Ahram Foundation for Press and Dubai Press Club, and these newspapers are: Al-Ahram (The Pyramids) as one of the largest state-owned newspapers circulation and also known as national newspapers, Al-wafd as one of the biggest and oldest political party-owned newspapers (partisan newspapers), and Al-Masry al-Youm as one of the largest private person ownership newspapers (Independent Press)(1). Masrawy is considered one of the largest and oldest access online news website in Egypt. A total of 1553 articles covering the 2010 Egyptian parliamentary campaign were gathered and analyzed in the period from November 8 to December 5 . The analysis included all features of content (news stories and opinion materials) in the 3 newspapers and the online web site related to the campaign. When the article included both kinds of candidates, it was divided into two or more articles each one dealing with one kind of gender of the candidates. The study used a form for articles analysis including the following coded categories:

Categories to represent demographic data (publication, date, and sex of the candidate). Other categories were applied to describe the volume of coverage for each gender of the candidates through the following units: 1- mentioning the candidate in the headline, 2- mentioning the candidate in the lead of the topic, 3- if the article is primarily about the candidate, 4- numbers of candidates' photos that accompanied the articles, 5- numbers of sentences that have been allocated to the candidate in the article.

Next category was created for a list of issues associated with candidates and divided into male issues (i.e., economy, unemployment, infrastructure, financial and administrative corruption, care and health insurance, international issues, poverty, environment, education, social welfare, democracy and human rights, relationships with parties, agriculture, Sectarian unity between Egyptian Muslims and Christians, and constitution amendment) and female issues (i.e., childcare, marriage and divorce, wages of working women, equal rights with men, widows and orphans' help, and Women's political participation). These issues were evolved from previous studies (Arceneaux 2001; Atkeson and Krebs 2008; Banwart et al 2003; Bystorm et al 2001; Celis 2004; Childs \& Krook 2005; Cowell-Meyers and Langbein 2006; Fridkin and Kenney 2008; Kahn and Goldenberg 1991; Schenk 2004) as well as from analyzing the content of the study sample. I considered poverty, care and health insurance, education as masculine issues, in contrast with previous studies (Banwart et al 2003; Bystrom et al 2001) which considered these issues as traditionally feminine issues because in Egypt they are some of strategic issues that underlie the development process and are related to other issues such as infrastructure, national income, and the standard of living. In addition, researchers define women's issues as those decreasing discrimination against women or countering its effects and improving the social, economic or political status of women (Cowell-Meyers and Langbein 2006: pp.5-7).

1 - For more details about categories of newspapers in Egypt see: El-Tantawy, Laura (2009). In The Shadow of the Pyramids: Case study of free expression in the Egyptian media, 2004-2009. Reuters institute for the study of Journalism, University of Oxford. 
Another category was created to list candidate personal traits and divided into two categories "masculine and feminine traits". Masculine traits branched two units: "toughness traits" to include all characteristics expressing the candidate ability to: competition, aggressiveness, fighting, ambition, decisiveness, strength, displaying initiative, and elusiveness, and "competence traits" including all characteristics expressing the candidate in a manner of: leadership, experience, incisiveness, knowledgeability, intellectual acuity, and capability. The second type of feminine traits branched two units: "honesty traits" which included all characteristics related to the candidate in a manner of: integrity, trustworthiness, conscientiousness, flexibility, and dedication, while "compassion traits" included all characteristics reflecting the candidate in a manner of: emotionality, understanding, consideration, gentleness, and enthusiasm. These personal traits were evolved from previous studies (Atkeson and Krebs 2008; Bligh and Kohles 2008; Carlson 2001; Celis 2004; Fridkin Kenney 2008; Heldman 2006; Kahn1994; Kahn and Goldenberg 1991; Valenzuela Correa 2009). Each trait in all categories (coded as positive $=+1$, neutral $=0$ or negative $=-1$ ).

The next category tackled framing coverage of the candidate in the horse-race. The study used previous work (Devitt 2002) which classified the campaign framing according to the gender of the candidate as the following codes: 1determining "issue frame" if paragraphs described candidates by their positions or actions on public policy issues. 2determining "personal frame" by the candidate's personal or professional background. 3- determining "strategic frame" by strategic or horse-race descriptions of the candidate-e.g., whether or not the candidate was ahead, the tactics the candidate used to get votes, and where the candidate campaigned (p.452). Another category was created to assign the "candidate background" and coded in three variables: qualifications, accomplishments or failures of the candidate.

Categories associated to the slant of the coverage were coded to evaluate if the coverage of the candidate was: positive, negative, neutral or equal focus (positive and negative). Another category mattered the classifying of the candidate electability and was coded to judge if the article considered the candidate overall competitive, likely winner, non- competitive or not obvious. These categories of slant and electability of the candidate were evolved from previous studies (Atkeson and Krebs 2008; Banwart et al 2003; Bystrom et al 2001; Valenzuela Correa 2009). The last category related to reporter's gender to determine if the article written by a female, male, both male and female, or could not determine the gender.

\section{Findings and Discussion}

\subsection{Quantity of journalism coverage and Candidate gender}

Based on previous research, I expected in the first hypothesis differences in the amount of coverage to find a bias favor of male candidates. $\chi 2$ test presents some support for this hypothesis in the total volume of press coverage for male candidates than those for females $\chi 2$ ( $N=1316$ articles vs. $N=237$ articles, $p<.001)=749.672$.

Table 1 through Chi-square test also presents significant differences in addressing both types of candidates within the topics to find another support to first hypothesis, that male candidates were mentioned in headlines, leads of the topics and were allocated primarily in the topics more than female candidates.

Table1: Quantity of Journalism Coverage

\begin{tabular}{|c|c|c|c|c|}
\hline \multirow{2}{*}{$\begin{array}{l}\text { Address the Candidate } \\
\text { Within the Topic }\end{array}$} & \multicolumn{2}{|c|}{ Sex of the Candidate } & \multirow{2}{*}{$\begin{array}{c}\text { Chi-Square } \\
\left(x^{2}\right)\end{array}$} & \multirow{2}{*}{$\begin{array}{c}\text { Exact Sig. } \\
\text { (1-sided) }\end{array}$} \\
\hline & Male $n=1316$ & Female $n=237$ & & \\
\hline Headline & $741(47.7 \%)$ & $98(6.3 \%)$ & 18.088 & .000 \\
\hline Lead of the Topic & $1010(65.0 \%)$ & $133(8.6 \%)$ & 43.987 & .000 \\
\hline Primarily About Candidate & $1149(74.0 \%)$ & $165(10.6 \%)$ & 48.264 & .000 \\
\hline
\end{tabular}

Degree of freedom $(\mathrm{df})=1$

To test the other variables associated with addressing the candidate within the topic Table 2 through $T$ test indicates no differences in mean of photos for male and female candidates but there are significant differences in mean of sentences for the candidate, that male candidates received more amount of sentences than females. 
Table 2: Quantity of Photos and Sentences

\begin{tabular}{|c|c|c|c|c|c|c|c|}
\hline \multirow{2}{*}{$\begin{array}{l}\text { Address } \\
\text { the Candidate } \\
\text { Within the Topic }\end{array}$} & \multicolumn{2}{|c|}{ Mean } & \multicolumn{2}{|c|}{ Std. Deviation } & \multicolumn{3}{|c|}{ t-test for Equality of Means } \\
\hline & $\begin{array}{l}\text { Male } \\
N=1316\end{array}$ & $\begin{array}{r}\text { Female } \\
N=237\end{array}$ & Male & Female & $\mathbf{t}$ & $D f$ & $\begin{array}{c}\text { Sig. } \\
\text { (2-tailed) }\end{array}$ \\
\hline $\begin{array}{l}\text { Photos for } \\
\text { the Candidate }\end{array}$ & .58 & .50 & .73 & .68 & 1.47 & 1551 & .141 \\
\hline $\begin{array}{l}\text { Sentences for } \\
\text { the Candidate }\end{array}$ & 13.30 & 8.58 & 14.94 & 13.04 & 4.56 & 1551 & .000 \\
\hline
\end{tabular}

My findings are consistent with some studies revealing that female candidates running for either U.S. Senate or gubernatorial seats receive less coverage than do their male counterparts (Kahn 1994; Kahn \& Goldenberg 1991), but are contrast to other studies showing that female candidates running for either U.S. governor or senate receive more coverage (Banwart et al 2003; Bystrom et al 2001) or equal coverage with male candidates (Atkeson and Krebs 2008; Devitt 1999, 2002; smith 1997).

\subsection{Issues mentions in the coverage and candidate gender}

Table 3 provides some support for the second hypothesis that male candidates received more attention on male issues than female candidates, whereas female candidates received more attention on female issues than male candidates. With regard to male issues there were some biases of nine issues that were covered for male candidates more than females: economy, unemployment, infrastructure, corruption, care and health insurance, poverty, relationships with parties, agriculture and constitution amendment. While there were no significant differences between male and female candidates with regard to the other 6 male issues: international issues, environment, education, social welfare, democracy and human rights and sectarian unity. Table 3 indicates biases of linking all females issues - except for childcare - to female candidates more than males (marriage and divorce, wages and working women, equal rights with men, widows and orphan's help and women's political participation).

Table 3: Issues Mentions in Coverage

\begin{tabular}{|c|c|c|c|c|c|}
\hline \multirow{2}{*}{ Issues } & & \multicolumn{2}{|c|}{ Sex of the Candidate } & \multirow{2}{*}{$\begin{array}{l}\text { Chi-Square } \\
\left(x^{2}\right)\end{array}$} & \multirow{2}{*}{$\begin{array}{l}\text { Exact Sig. } \\
\text { (1-sided) }\end{array}$} \\
\hline & & Male $N=1316$ & Female $N=237$ & & \\
\hline Male & Economy & $86(5.5 \%)$ & $7(.5 \%)$ & 4.575 & .017 \\
\hline \multirow[t]{14}{*}{ Issues } & Unemployment & $156(10.0 \%)$ & $14(.9 \%)$ & 7.286 & .003 \\
\hline & Infrastructure & $230(14.8 \%)$ & $19(1.2 \%)$ & 13.351 & .000 \\
\hline & Corruption & $102(6.6 \%)$ & $6(.4 \%)$ & 8.454 & .001 \\
\hline & Care \& health insurance & $159(10.2 \%)$ & $15(1.0 \%)$ & 6.681 & .005 \\
\hline & Intemational issues & $19(1.2 \%)$ & $1(.1 \%)$ & 1.650 & .166 \\
\hline & Poverty & $62(4.0 \%)$ & $4(.3 \%)$ & 4.512 & .018 \\
\hline & Environment & $47(3.0 \%)$ & $6(.4 \%)$ & .659 & .278 \\
\hline & Education & $114(7.3 \%)$ & $13(.8 \%)$ & 2.700 & .060 \\
\hline & Social welfare & $53(3.4 \%)$ & $5(.3 \%)$ & 2.054 & .101 \\
\hline & Democracy \&human rights & ts $\quad 26(1.7 \%)$ & $6(.4 \%)$ & .308 & .361 \\
\hline & Relationships with parties & $216(13.9 \%)$ & $26(1.7 \%)$ & 4.523 & .018 \\
\hline & Agriculture & $83(5.3 \%)$ & $6(.4 \%)$ & 5.299 & .011 \\
\hline & Sectarian unity & $35(2.3 \%)$ & $10(.6 \%)$ & 1.737 & .135 \\
\hline & Constitution Amendment & $16(1.0 \%)$ & $8(.5 \%)$ & 6.157 & .021 \\
\hline \multirow{6}{*}{$\begin{array}{l}\text { Femal } \\
\text { Issues }\end{array}$} & e Childcare & $5(.3 \%)$ & $3(.2 \%)$ & 3.075 & .109 \\
\hline & Marriage and divorce & $1(.1 \%)$ & $5(.3 \%)$ & 21.583 & .000 \\
\hline & Wages of working women & $2(.1 \%)$ & $3(.2 \%)$ & 7.764 & .028 \\
\hline & Equal rights with men & $3(.2 \%)$ & $5(.3 \%)$ & 13.876 & .003 \\
\hline & Widows and orphans' help & $4(.3 \%)$ & $14(.9 \%)$ & 55.039 & .000 \\
\hline & Women's political participa & pation $4(.3 \%)$ & $6(.4 \%)$ & 15.578 & .001 \\
\hline
\end{tabular}

Degree of freedom $(\mathrm{df})=1$

My findings are different from other studies which concluded that women did not receive more attention on female issues nor did they receive less on male issues in their mayoral races (e.g., Atkeson and Krebs 2008), but they are consistent with some studies which revealed that men were more likely to be associated with such masculine issues (e.g., Banwart et al 2003; Bystrom et al 2001; Fridkin and Kenney 2008). Although such studies considered some issues like poverty, care and health insurance, education as feminine issues, I had analyzed them as masculine issues. Therefore they found that men were more likely to be associated with such feminine issues. The frequencies of female issues covered in 
Egyptian press were few compared to male issues(2), yet findings suggest that women's issues when appeared in the topics were strongly affiliated to female candidates. Overall, although some of male issues were consistently associated with men and women candidates in Egyptian journalism coverage, men candidates received more stereotypical association with masculine issues.

Table 4: Traits Mentions in Coverage

\begin{tabular}{|c|c|c|c|c|c|c|}
\hline \multirow[b]{2}{*}{ Traits } & \multicolumn{2}{|l|}{ Mean } & \multicolumn{2}{|c|}{ Std. Deviation } & \multicolumn{2}{|c|}{ t-test for Equality of Means } \\
\hline & $\begin{array}{l}\text { Male } \\
N=1316\end{array}$ & $\begin{array}{r}\text { Female } \\
N=237\end{array}$ & Male & Female & t & $\begin{array}{l}\text { Sig. } \\
\text { (2-tailed) }\end{array}$ \\
\hline \multicolumn{7}{|l|}{$\begin{array}{l}\text { Male Personal Traits } \\
\text { 1-Toughness }\end{array}$} \\
\hline Competition & .19 & .13 & .47 & .33 & 2.110 & .035 \\
\hline Aggressiveness & .09 & .03 & .29 & .17 & 3.253 & .001 \\
\hline Fighting & .08 & .05 & .28 & .21 & 1.967 & .049 \\
\hline Ambition & .14 & .07 & .35 & .26 & 2.828 & .005 \\
\hline Decisiveness & .05 & .01 & .21 & .09 & 2.762 & .006 \\
\hline Strength & .10 & .02 & .40 & .16 & 3.284 & .001 \\
\hline Displaying initiative & .17 & .08 & .40 & .29 & 3.433 & .001 \\
\hline Elusiveness & .03 & .00 & .17 & .00 & 2.689 & .007 \\
\hline \multicolumn{7}{|l|}{ 2-Competence } \\
\hline Leadership & .02 & .01 & .19 & .09 & 1.215 & .225 \\
\hline Experience & .09 & .08 & .31 & .27 & .859 & .390 \\
\hline Incisiveness & .05 & .03 & .25 & .17 & 1.269 & .205 \\
\hline Knowledgeability & .02 & .01 & .15 & .09 & 0.822 & .411 \\
\hline Intellectual acuity & .02 & .01 & .15 & .09 & 0.944 & .345 \\
\hline Capability & .07 & .00 & .42 & .24 & 2.215 & .027 \\
\hline \multicolumn{7}{|c|}{ Female Personal Traits } \\
\hline \multicolumn{7}{|c|}{ 1-Honesty } \\
\hline Integrity & .00 & .00 & .08 & .22 & .884 & .377 \\
\hline Trustworthiness & .00 & .01 & .03 & .24 & -1.11 & .268 \\
\hline Conscientiousness & .00 & .10 & .03 & .30 & -11.81 & .000 \\
\hline Dedication & .00 & .08 & .06 & .28 & -9.32 & .000 \\
\hline \multicolumn{7}{|l|}{ 2-Compassion } \\
\hline Emotionality & .00 & .02 & .05 & .13 & -3.09 & .002 \\
\hline Understanding & .00 & .01 & .03 & .11 & -3.34 & .001 \\
\hline Consideration & .00 & .03 & .05 & .16 & -4.32 & .000 \\
\hline Gentleness & .00 & .03 & .03 & .18 & -6.23 & .000 \\
\hline Enthusiasm & .00 & .06 & .05 & .24 & -8.25 & .000 \\
\hline
\end{tabular}

Degree of freedom $(\mathrm{df})=1551$

\subsection{Traits mentions in the coverage and candidate gender}

Table 4 through $T$ test shows a strong support to the third hypothesis, that the all eight personal traits included in "toughness" - the first classification of male traits- are significantly linked with male more than female candidates (competitiveness, aggressiveness, fighting, ambition, decisiveness, strength, displaying initiative, and elusiveness). While in "competence" -the second classification of male personal traits- there were no significant differences between male and female candidates with regard to five of the six personal traits (leadership, experience, incisiveness, knowledgeability and intellectual acuity), while the sixth trait "capability" only in this classification linked with male more than female candidates.

The first classification of female personal traits " honesty" as shown in Table 4 indicates significant linking with female more than male candidates with reference to both conscientiousness and dedication traits, but there are no differences with regard to both integrity and trustworthiness traits(3). The second classification of female traits "compassion" gives a strong support to the third hypothesis, that its five traits are significantly linked with female more than male candidates (emotionality, understanding, consideration, gentleness and enthusiasm) as shown in Table 4.

My findings are consistent with recent study (Fridkin and Kenney 2008) analyzing 2006 U.S. senate campaign that concluded women senators were viewed as more honest and more caring than male senators. These findings come in contrast to other previous studies which revealed that the portrayal of candidate image traits did not differ significantly between the primary coverage and general election coverage for either female or male candidates except on the image strategy of using an "above the trenches" posture (Banwart et al 2003: 672) or male and female candidates received

2 - The frequencies of those issues were: childcare $=8$, marriage and divorce $=6$, wages of working women $=5$, equal rights with men $=8$, widows and orphans' help $=18$ and women's political participation $=10$.

3 - Flexibility was excluded from "Honesty" classification because its frequency scored twice in the analysis. 
more feminine image traits such as honesty and such elements of feminine style as use of personal tone and addressing voters as peers (Bystrom et al 2001). Also my findings are different from previous works investigating in televised advertising to find that men are more likely than women to stress honesty in their political advertisements (Banwart 2002 cited in Banwart et al 2003).

\subsection{The coverage of frames and background according to candidate gender}

Table 5 through Chi-square test illuminates a strong support to the fourth hypothesis, that male candidates received strategic and issue coverage more than female candidates who received more personal coverage than male candidates.

These finding are consistent with studies at the legislative and governor level (Banwart et al 2003; Bystrom et al 2001; Devitt 2002) and with studies at the presidential level (Aday and Devitt 2001; Heldman et al 2005) that showed a consistent difference between male and female candidates in this dimension. In contrast, in the coverage of local races Atkeson and Krebs (2008) found the presence of a woman on the ballot tends to enhance the salience of female or compassion issues, alter coverage of candidates' personality traits, and increase overall coverage of nonpolicy family and appearance coverage. Also my findings come contrary to research at political advertising that showed women candidates are no more likely than men candidates to mention their children or material status in their commercials (Bystrom and Miller 1997) and women are less likely than men to show their families on their Web sites (Banwart and Kaid 2002; Bystrom 2006b; Niven and Zilber 2001; Schenk 2004).

In the study by Devitt (2002), he diminished the argument that female candidates may receive more personal coverage than do male candidates because they are new to politics and thus need to be introduced to the electorate as both an individual and a candidate (p. 454) I found this situation is applied to the new Egyptian experiment that had assigned quota for women candidates in parliamentary elections to provide an opportunity for the participation of large numbers of women in the race for the first time. Therefore I found men candidates were associated with strategy and issue frames more than women.

Table 5: Mentioning Frames and Background in Coverage

\begin{tabular}{|c|c|c|c|c|}
\hline \multirow{2}{*}{$\begin{array}{l}\text { Candidate } \\
\text { Focus }\end{array}$} & \multicolumn{2}{|c|}{ Sex of the Candidate } & \multirow{2}{*}{$\begin{array}{c}\text { Chi-Square } \\
\left(\chi^{2}\right)\end{array}$} & \multirow{2}{*}{$\begin{array}{l}\text { Exact Sig. } \\
\text { (1-sided })\end{array}$} \\
\hline & $\begin{array}{c}\text { Male } \\
n=1316\end{array}$ & $\begin{array}{r}\text { Female } \\
n=237\end{array}$ & & \\
\hline \multicolumn{5}{|l|}{ Candidate Frames } \\
\hline Strategic Frame & $978(63.0 \%)$ & $150(9.7 \%)$ & 12.281 & .000 \\
\hline Personal Frame & $1(.1 \%)$ & $21(1.4 \%)$ & 110.978 & .000 \\
\hline Issue Frame & $415(26.7 \%)$ & $61(3.9 \%)$ & 3.175 & .043 \\
\hline \multicolumn{5}{|c|}{ Candidate Background } \\
\hline Qualifications & $365(23.5 \%)$ & $66(4.2 \%)$ & .001 & .514 \\
\hline Accomplishments & $358(23.1 \%)$ & $26(1.7 \%)$ & 28.434 & .000 \\
\hline Failures & $189(12.2 \%)$ & $24(1.5 \%)$ & 3.044 & .047 \\
\hline
\end{tabular}

Degree of freedom $(\mathrm{df})=1$

Table 5 also illuminates a strong support to the fourth hypothesis regarding the existence of differences in background covered in Egyptian press according to the gender of the candidate, that male candidates received accomplishments and failures coverage more than female candidates, while there were no significant differences in qualifications coverage.

The implications behind these findings may prove detrimental to female candidates as they do not have the experience or the enough participation in political and social life that result in the availability of information about their accomplishments and failures, and therefore focus more on their qualifications to the degree that led them to be equal with male candidates in the coverage.

\subsection{Electability and slant of coverage according to candidate gender}

Table 6 reveals no support to the fifth hypothesis with regard to the slant of coverage, that although there were significant differences, both male and female received more positive coverage than either neutral or negative coverage. Male and female candidates were more likely to receive positive coverage followed by neutral coverage and the negative coverage in the race.

These findings come in contrast with previous studies (Bystrom et al 2001) illuminating women and men candidates were treated almost equally, but they received mostly neutral coverage, though the negative coverage of both 
outweighed their positive coverage. More recent studies suggested that the slant of male candidates' news coverage became more negative, whereas female candidate coverage remained more neutral from the primary to general election. Yet, these advantages did not translate to greater discussions of female candidates' viability in these races, as viability coverage remained equitable for female and male candidates during both the primaries and general election (Banwart et al 2003: 673).

Table 6: The Slant of Coverage

\begin{tabular}{|c|c|c|c|c|c|}
\hline \multirow{2}{*}{$\begin{array}{l}\text { Sex of } \\
\text { the Candidate }\end{array}$} & \multicolumn{3}{|c|}{ Slant in Articles } & \multicolumn{2}{|c|}{ Chi-Square Asymp } \\
\hline & Positive & Negative & Neutral & $\left(x^{2}\right)$ & Sig. \\
\hline Male $N=1187$ & 663( & $181(15.2 \%)$ & $343(28.9 \%)$ & 304.101 & .000 \\
\hline Female $N=224$ & $108(48.2 \%)$ & $30(13.4 \%)$ & $86(38.4 \%)$ & 43.321 & .000 \\
\hline
\end{tabular}

Degree of freedom $(\mathrm{df})=2$

Note: "Equal focus" (positive and negative) responses were removed from analysis

Table 7 also reveals no support to the fifth hypothesis with regard to candidate electability coverage, that although there were significant differences, both male and female received more likely winner followed by competitive and noncompetitive.

In my study, men and women candidates' equivalence in the slant of coverage to receive more positive coverage than neutral and negative coverage integrates with their electability as they were covered mostly likely winner followed by competitive and non- competitive. This finding is contrary to earlier work (Kahn 1996; Kahn and Goldenberg 1991) revealing that female candidates' viability coverage is more negative than that of their male counterparts, while more recent study (Bystrom et al 2001) concluded that women candidates were not discussed more frequently in terms of their viability. In fact, about one third of the coverage of female and male candidates focused on their viability and the other two thirds of the articles covering their campaigns did not mention their potential for success (p.2009).

Table 7: Mentioning Candidate Electability in Coverage

\begin{tabular}{|c|c|c|c|c|c|}
\hline Sex of & & ndidate electab & & Chi-Square & Asymp. \\
\hline the Candidate & Competitive & Likely winner & Non-competitive & $\left(x^{2}\right)$ & Sig. \\
\hline Male $\mathrm{N}=956$ & $194(20.3 \%)$ & $668(69.9 \%)$ & $94(9.8 \%)$ & 590.117 & .000 \\
\hline Female $N=135$ & $26(19.3 \%)$ & $100(74.1 \%)$ & $9(6.7 \%)$ & 104.044 & .000 \\
\hline
\end{tabular}

Degree of freedom $(\mathrm{df})=2$

Note: "Not obvious" responses were removed from analysis.

Furthermore, in the study of Atkeson and Krebs (2008) which used state or local press organizations covering candidates mayoral campaign they noticed while in examining their data across intergender and intragender contests for one measure of electability and experience measure that the male eventual winner in the all male race is actually favored compared to the female eventual winner in the intergender race (P.249). Findings of this previous work are different from my findings as they suggested that the content of news stories might be produced from an interaction between the content of the campaign (e.g., gender issues) and sex stereotypes (P.250). But in the Egyptian parliamentary campaign the most of races were intragender contests, and the analysis of the newspapers and Masrawy web site was not limited to news stories but extended to the various features of media content. Interestingly, Al-wafd ,the partisan newspaper, was used to specify regular coverage of the both gender candidates in order to publicize them, and the same coverage emerged at Masrawy web site which published profiles of candidates who were interested in publicity for themselves free of charge on the web. This positive coverage, together with propaganda matters, resulted in the appearance of men and women candidates as winner in various conditions.

\subsection{Reporter's gender and the quantity of coverage}

Table 8 shows that male reporters wrote 1017 (86.3\%) of the 1179 articles written by either a male or female reporter and (65.5\%) of all 1553 articles analyzed. Although male reporters wrote significantly more articles than their female colleagues, female reporters have no bias favor of female candidates, that both male and female authors wrote about male candidates more than females. This result, though revealing no support to the sixth hypothesis which predicted that 
there are differences in volume of coverage of female and male candidate according to the gender of the editor, illuminates that male candidates received more coverage than female from both genders of authors.

Table 8: Reporter's Gender and the quantity of Covering Candidate

\begin{tabular}{lcccc}
\hline $\begin{array}{l}\text { Sex of the } \\
\text { Editor }\end{array}$ & \multicolumn{2}{c}{$\begin{array}{c}\text { Sex of the Candidate } \\
\text { Male }\end{array}$} & $\begin{array}{c}\text { Female } \\
\text { Chi-Square } \\
\left(\chi^{2}\right)\end{array}$ & $\begin{array}{c}\text { Asymp. Sig. } \\
(1-\text {-sided })\end{array}$ \\
\hline Male $(\mathrm{N}=1017)$ & $878(86.3 \%)$ & $139(13.7 \%)$ & & \\
Female $(\mathrm{N}=162)$ & $\begin{array}{c}129(79.6 \%) \\
\text { (Valid }=1179)\end{array}$ & $33(20.4 \%)$ & 5.038 & .019 \\
\hline
\end{tabular}

Degree of freedom $(\mathrm{df})=1$

Note: "Both male and female" and "Could not determine the gender of the reporter" responses related to sex of the editor were removed from analysis.

\subsection{Electability and slant of coverage according to reporter's gender}

Table 9 shows a partial support to the seventh hypothesis with regard to male authors who wrote more positively about male candidates followed by neutral coverage and negative coverage in the race, whereas they wrote more neutrally about female candidates followed by positive coverage and negative coverage. With regard to female authors there were no significant differences in their covering slant of male and female candidates. This finding is in contrast with earlier work about gender differences in U.S. senate campaign coverage (Kahn and Goldenberg 1991) showing that male reporters appear to be more neutral in their coverage, or in presidential campaign coverage (Valenzuela and Correa 2009) that there were no significant differences in the way female and male reporters covered "Bachelet" -the presidential woman candidate in Chile.

Table 9: Reporter's Gender and Slant of Covering Candidate

\begin{tabular}{|c|c|c|c|c|c|}
\hline \multirow{2}{*}{$\begin{array}{l}\text { Sex of the } \\
\text { Editor }\end{array}$} & \multirow[t]{2}{*}{ Slant } & \multicolumn{2}{|c|}{ Sex of the Candidate } & \multirow{2}{*}{$\begin{array}{l}\text { Chi-Square } \\
\left(x^{2}\right)\end{array}$} & \multirow{2}{*}{$\begin{array}{l}\text { Asymp. Sig. } \\
\text { (2-sided) }\end{array}$} \\
\hline & & Male & Female & & \\
\hline \multirow{3}{*}{$\begin{array}{l}\text { Male } \\
\mathrm{N}=923\end{array}$} & Positive & $408(51.7 \%)$ & $51(38.1 \%)$ & \multirow{3}{*}{10.019} & \multirow{3}{*}{.007} \\
\hline & Negative & $125(15.8 \%)$ & $22(16.4 \%)$ & & \\
\hline & Neutral & $256(32.4 \%)$ & $61(45.5 \%)$ & & \\
\hline \multirow{2}{*}{$\begin{array}{c}\text { Female } \\
\mathrm{N}=144\end{array}$} & Positive & $64(55.2 \%)$ & $21(24.7 \%)$ & \multirow[b]{2}{*}{3.908} & \multirow[b]{2}{*}{.142} \\
\hline & $\begin{array}{l}\text { Negative } \\
\text { Neutral }\end{array}$ & $\begin{array}{l}21(18.1 \%) \\
31(26.7 \%)\end{array}$ & $2(8.7 \%)$ & & \\
\hline ralid & (Missin & :486) & & & \\
\hline
\end{tabular}

Degree of freedom $(\mathrm{df})=2$

Note: 1- "Equal focus" (positive and negative) responses related to slant were removed from analysis. 2- "Both male and female" and "Could not determine the gender of the reporter" responses related to sex of the editor were removed from analysis.

But Table 10 shows no support to the seventh hypothesis concerning the differences in the candidate electability coverage of male and female candidates according to the sex of the reporter.

Table 10: Reporter's Gender and Electability of Covering Candidate

\begin{tabular}{|c|c|c|c|c|c|}
\hline \multirow{2}{*}{$\begin{array}{l}\text { Sex of the } \\
\text { Editor }\end{array}$} & \multirow{2}{*}{$\begin{array}{c}\text { Candidate } \\
\text { Electability }\end{array}$} & \multicolumn{2}{|c|}{ Sex of the Candidate } & \multirow{2}{*}{$\begin{array}{c}\text { Chi-Square } \\
\left(x^{2}\right)\end{array}$} & \multirow{2}{*}{$\begin{array}{c}\text { Asymp. Sig. } \\
\text { (2-sided) }\end{array}$} \\
\hline & & Male & Female & & \\
\hline \multirow{3}{*}{$\begin{array}{l}\text { Male } \\
(\mathrm{N}=745)\end{array}$} & Competitive & $140(21.2 \%)$ & $17(20.0 \%)$ & \multirow{3}{*}{2.321} & \multirow{3}{*}{.313} \\
\hline & Likely winner & $448(67.9 \%)$ & $63(74.1 \%)$ & & \\
\hline & & & (1.07) & & \\
\hline \multirow{2}{*}{$\begin{array}{l}\text { Female } \\
(\mathrm{N}=113)\end{array}$} & $\begin{array}{l}\text { Competitive } \\
\text { Likely winner }\end{array}$ & $\begin{array}{l}14(14.9 \%) \\
69(73.4 \%)\end{array}$ & $\begin{array}{c}5(26.3 \%) \\
14(73.7 \%)\end{array}$ & \multirow{2}{*}{3.450} & \multirow{2}{*}{.178} \\
\hline & Non-competitive & $11(11.7 .0 \%)$ & $0(00 \%)$ & & \\
\hline (Valid $=858$ & (Missing $=6$ & 95) & & & \\
\hline
\end{tabular}

Degree of freedom $(\mathrm{df})=2$

Note: 1- "Not obvious" responses related to candidate electability were removed from analysis. 2- "Both male and female" and "Could not determine the gender of the reporter" responses related to sex of the editor were removed from analysis. 


\subsection{Reporter's gender and the coverage of frame and background}

Table 11 shows a strong support to the eighth hypothesis that male reporters wrote significantly more strategic frames for men candidates than for women, while there were no significant differences in strategic frames used by female reporters to cover men and women candidates. Although personal frames were covered fewer than strategic and issue frames (7 articles wrote by male authors and 8 articles by female authors), both male and female authors wrote significantly more personal frames for women candidates than men and the all 8 personal frames in articles wrote by female authors were dedicated to women candidates.

Table 11: Covering Frame and Background of the Candidate and Editor's Gender

\begin{tabular}{|c|c|c|c|c|c|}
\hline \multirow{2}{*}{$\begin{array}{l}\text { Sex of the } \\
\text { Editor }\end{array}$} & \multirow{2}{*}{$\begin{array}{l}\text { Candidate } \\
\text { presented }\end{array}$} & \multicolumn{2}{|c|}{ Sex of the Candidate } & \multirow{2}{*}{$\begin{array}{c}\text { Chi-Square } \\
\left(\chi^{2}\right)\end{array}$} & \multirow{2}{*}{$\begin{array}{c}\text { Asymp. Sig. } \\
\text { (1-sided) }\end{array}$} \\
\hline & & Male & Female & & \\
\hline \multicolumn{6}{|c|}{ Candidate Frames } \\
\hline Male & Strategic & $677(88.4 \%)$ & $89(11.6 \%)$ & 11.042 & .001 \\
\hline$(\mathrm{N}=1017)$ & Personal & $1(14.3 \%)$ & $6(85.7 \%)$ & 31.007 & .000 \\
\hline \multirow{4}{*}{$\begin{array}{l}\text { Female } \\
(\mathrm{N}=162)\end{array}$} & Issue & $261(87.6 \%)$ & $37(12.4 \%)$ & .560 & .261 \\
\hline & Strategic & $107(81.1 \%)$ & $25(18.9 \%)$ & .900 & .238 \\
\hline & Personal & $0(00 \%)$ & $8(100.0 \%)$ & 32.897 & .000 \\
\hline & issue & $40(90.9 \%)$ & $4(9.1 \%)$ & 4.738 & .021 \\
\hline \multicolumn{6}{|c|}{ Candidate Background } \\
\hline Male & Qualifications & $232(87.5 \%)$ & $33(12.5 \%)$ & .448 & .289 \\
\hline \multirow[t]{2}{*}{$(\mathrm{N}=1017)$} & Accomplishments & $227(93.0 \%)$ & $17(7.0 \%)$ & 12.214 & .000 \\
\hline & Failures & $121(87.7 \%)$ & $17(12.3 \%)$ & .246 & .366 \\
\hline Female & Qualifications & $27(71.1 \%)$ & $11(28.9 \%)$ & 2.252 & .104 \\
\hline \multirow[t]{2}{*}{$(\mathrm{N}=162)$} & Accomplishments & $40(90.9 \%)$ & $4(9.1 \%)$ & 4.738 & .021 \\
\hline & Failures & $28(93.3 \%)$ & $2(6.7 \%)$ & 4.263 & .027 \\
\hline
\end{tabular}

Degree of freedom (df) $=1$

Note: "Both male and female" and "Could not determine the gender of the reporter" responses related to sex of the editor were removed from analysis.

There were no significant differences in issue frames wrote by male reporters to cover men and women candidates, but their female colleagues covered significantly issue frames for male candidates more than female candidates.

These findings are partly consistent with former work of how newspapers covered Elizabeth Dole's presidential bid (Aday and Devitt 2001) that found compared to her male opponents, Dole received less coverage on her positions on the issues but more coverage on her personal traits and these differences were due to stories written by male reporters covering the 2000 presidential campaign.

The findings of the study of Aday and Devitt (2001) are incompatible with another study analyzing presidential campaign coverage in Chile (Valenzuela and Correa 2009) which concluded that the gender of reporter did not account for any significant difference in the way the female candidate was covered, except in the case of frequency of mentions of Bachelet's sex, or other previous study which analyzed the coverage of gubernatorial campaign (Devitt 2002: 458) illuminating that female reporters employed about the same percentage of issue and personal frames for both men and women candidates within the same campaign. The study of the coverage of 2010 Egyptian parliamentary campaign reveals that male authors were interested in covering men candidates by their actions, or tactics (strategic frame) used in the horse-race to get votes more than they were interested in women candidates, while female authors were more equitable in how they framed this strategy for both gender of candidates than were male reporters. Although the frequencies of personal frames were few in the current study, when appeared, both male and female authors used these frames with women candidates more than they did with men candidates.

Table 11 also shows no support to the eighth hypothesis, that there were no significant differences in both qualifications and failures background wrote by male authors to cover male and female candidates, whereas both male and female reporters wrote significantly more accomplishments background for men candidates than for women, and female authors wrote more failures background for men candidates than for women, while there were no significant differences in qualifications background used by female authors to cover male and female candidates.

My findings of hypothesis 8 are consistent with previous results illuminating a strong support to hypothesis 4 that male candidates received accomplishments and failures coverage more than female candidates who do not have the experience or the enough participation in political and social life that result in the availability of information about their accomplishments and failures. 


\section{Conclusion}

Overall, The analysis of Egyptian journalism coverage of 2010 parliamentary election campaign illuminated a bias favor of male candidates both quantitatively and qualitatively. Yes, feminist phenomenology was present in the coverage, and although feminine issues and traits appeared slightly in the coverage they attached to women candidates more than men. Also male and female candidates were framed differently beside differences in background according to their gender. However, the slant and electability of coverage were equitable to men and women candidates. Furthermore, there were some differences in how male and female journalists covered men and women candidates specially with regard to amount and slant of the coverage, framing and background of the candidate.

\section{Recommendations}

This study not only sheds light on results regarding the equality of Egyptian journalism coverage quantitatively and qualitatively for female and male candidates running in legislative election races but also raises important proposals for future research. There is a need for more direct comparative analysis of candidates' messages agendas versus those perpetuated by the media in mixed-gender races (Banwart et al 2003: 673) or to explore how women legislators position themselves within a "space of action" that intersection of multiple discourses makes available (Bligh an Kohles 2008: 397) through analyzing the descriptive and substantive representation of women (Childs and Krook 2005) legislators in the media, given the fact that there are various political currents including Islamic, Liberal, Leftist and Independent political streams in Egypt pushing their women candidates to act in the Legislation Councils. In addition, press coverage of women candidates' studies in Arabic countries need to look for the effects of this coverage on public opinion toward female candidates and their stereotype which plays a role in the vote decision. These effects require a comparative analysis of different categories of newspapers, particularly in Egypt, according to their ideological affiliation.

It is more likely to see into the ways in which women legislators as leaders may use language to creatively position themselves within both masculinity and femininity discourses (Bligh an Kohles 2008) and how media coverage reflects their manipulation of the leadership landscape and the influence of this coverage on perceptions of leadership effectiveness.

\section{References}

Aday, S. \& Devitt, J. (2001). Style over substance: Newspaper coverage of Elizabeth Dole's presidential bid. Harvard International Journal of Press/Politics, 6(2): 52-73.

Arceneaux, K. (2001). The gender gap in state legislative representation: New data to tackle an old question. Political Research Quarterly, 54(1): 143-160.

Atkeson, L. R. \& Krebs, T. B. (2008). Press coverage of mayoral candidates: The role of gender in news reporting and campaign issue speech. Political Research Quarterly, 61(2): 239-252.

Banwart, M. C. \& Kaid, L. L. (2002). Videostyle and webstyle in 2000: An interchannel comparison of candidate self presentation. Paper presented at the Annual Meeting of the American Political Science Association, Boston. August 29-Sept. 1.

Banwart, M. C., Bystrom, D. G. \& Robertson, T. A. (2003). From the primary to the general: A comparative analysis of candidate media coverage in mixed-gender 2000 races for governor and U.S. Senate. American Behavioral Scientist, 46: 658-676.

Bligh, M. C. \& Kohles, J. C. (2008). Negotiating gender role expectations: Rhetorical leadership and women in the US Senate. Leadership, 4(4): 381-402.

Bystrom, D. G. (2006a). Advertising, web sites and media coverage: Gender and communication along the campaign trail. In S. Carroll \& R. Fox (Eds.), Gender and elections: Shaping the future of American politics (pp.169-188). New York: Cambridge University Press,.

Bystrom, D. G. (2006b). Gender and campaign communication: TV ads, web sites, and media coverage. UC Berkeley: Institute of Governmental Studies.

Bystrom, D. G. \& Miller, J. (1997). Campaigning for state vs. federal office: An analysis of the television spots of male and female gubernatorial and U.S. senate candidates. Paper presented at the National Communication Association 83 rd annual meeting, Chicago, IL, November 19-23.

Bystrom, D. G., McKinnon, L. M. \& Chaney, C. K. (1999). The first lady and the first estate: Media coverage of Hillary Clinton and Elizabeth Dole in 1996 presidential campaign. In L. L. Kaid \& D. G. Bystrom (Eds.), The electronic election: Perspectives on the 1996 campaign communication (pp. 81-95). Mahwah, NJ: Lawrence Erlbaum.

Bystrom, D. G., Banwart, M. C., Kaid, L. L. \& Robertson, T. A. (2004). Gender and candidate communication. New York: Routledge.

Bystrom, D. G., Robertson, T. A. \& Banwart, M. C. (2001). Framing the fight: An analysis of media coverage of female and male candidates in primary races for governor and U.S. Senate in 2000. American Behavioral Scientist, 44: 1999-2013.

Carlin, D. B. \& Winfrey, K. L. (2009). Have you come a long way, baby? Hillary Clinton, Sarah Palin, and sexism in 2008 campaign 
coverage. Communication Studies, 60 (4): 326-343.

Carlson, T. (2001). Gender and political advertising across cultures: A comparison of male and female political advertising in Finland and the US. European Journal of Communication, 16 (2): 131-154.

Celis, K. (2004). Substantive and descriptive representation: Investigating the impact of the voting right and of descriptive representation on the substantive representation of women in the Belgian Lower House (1900-1979). Paper presented at the Annual Meeting of the American Political Science Association, Chicago, IL, September 2-5.

Childs, S., \& Krook, M., (2005). The Substantive Representation of Women: Rethinking the 'Critical Mass' Debate. Paper presented at the Annual Meeting of the American Political Science Association, Washington, DC, September 1-4.

Cowell-Meyers, K. \& Langbein, L. (2006). Deconstructing women's policy in the US states. Paper presented at the Annual Meeting of the American Political Science Association, Philadelphia, Pa. August 31.

Devitt, J. (2002). Framing gender on the campaign trail: Female gubernatorial candidates and the press. Journalism and Mass Communication Quarterly, 79: 445-63.

Devitt, J. (1999). Framing gender on the campaign trail: Women's executive leadership and the press. Washington DC: The Woman's Leadership Fund.

El-Tantawy, L. (2009). In the shadow of the Pyramids: Case study of free expression in the Egyptian media, 2004-2009. UK: Reuters institute for the Study of Journalism, University of Oxford.

Fridkin, K. L. \& Kenney, P. J. (2008). The role of gender stereotypes in U.S. Senate Campaigns. Paper presented at the Annual Meeting of the American Political Science Association, Boston, MA, August 28-31.

Gershon, S. A. (2008). Media coverage of female and minority representatives. Paper presented at the Annual Meeting of the American Political Science Association, Boston, MA, August 28-31.

Gidengil, E. \& Everitt, J. (1999). Metaphors and Misrepresentation: Gendered mediation in news coverage of the 1993 Canadian leaders debates. Harvard International Journal of Press/Politics, 4(1):48-65.

Gidengil, E. \& Everitt, J. (2003). Talking tough: Gender and reported speech in campaign news coverage. Political Communication, 20: 209-32.

Heldman, C. (2006). Commander in chief: Madame president in popular culture. Paper presented at the Annual Meeting of the American Political Science Association, Philadelphia, August 31 - September 3.

Heldman, C., Carroll, S. J. \& Olson, S. (2005). She brought only a skirt: print media coverage of Elizabeth Dole's bid for the republican presidential nomination. Political Communication, 22 (3): 315-35.

Jalazai, F. (2006). Women candidates and the media: 1992-2000 Elections. Politics and Policy, 34(3): 606-633.

Kahn, K. F. (1993). Gender differences in campaign messages: The political advertisements of men and women candidates for U.S. Senate. Political Research Quarterly, 46: 481-502.

Kahn, K. F. (1994). The distorted mirror: Press coverage of women candidates for statewide office. Journal of Politic, 56:154-73.

Kahn, K. F. (1996). The political consequences of being a women: How stereotypes influence the conduct and consequences of campaigns. New York: Columbia University Press.

Kahn, K. F. \& Goldenberg, E. N. (1991). Women candidates in the news: An examination of gender differences in U.S. senate campaign coverage. Public Opinion Quarterly, 55:180-99.

Niven, D. \& Zilber, J. (2001). Do women and men in congress cultivate different images? Evidence from congressional web sites. Political Communication, 18: 395-405.

Peake, J. S. \& Miller, M. K. (2008). Presidential primaries and the news: Coverage of the 2008 nomination campaign. Paper presented at the Annual Meeting of the American Political Science Association, Boston, MA, August 28-31.

Piper-Aiken, K. (1999). Gender factors in news media coverage of Madeleine K. Albright: A comparative content analysis. Paper presented at the Annual Meeting of the International Communication Association, San Francisco, CA, May.

Schenk, J. (2004). Gender differences on campaign web sites, 2002. Paper presented at the 2004 Annual Meeting of the Midwestern Political Science Association, Chicago, Illinois, April 15-18.

Smith, K. B. (1997). When all's fair: Signs of parity in media coverage of female candidates. Political Communication, 14:71-82.

Valenzuela, S. \& Correa, T. (2009). Press coverage and public opinion on women candidates: The case of Chile's Michelle Bachelet. The International Communication Gazette, 71(3): 203-223. 